\title{
Diversidade genética entre acessos de capim-elefante obtida com marcadores moleculares
}

\author{
Antonio Vander Pereira ${ }^{1^{*}}$, Marco Antonio Machado ${ }^{1}$, Ana Luisa Sousa Azevedo ${ }^{2}$, Carlos \\ Souza do Nascimento ${ }^{2}$, Ana Lúcia Campos ${ }^{1}$, Francisco José da Silva Lédo ${ }^{1}$
}

\footnotetext{
${ }^{1}$ Embrapa Gado de Leite, Rua Eugênio do Nascimento 610, Dom Bosco, CEP: 36038-330, Juiz de Fora, MG.

2 Universidade Federal de Viçosa, Departamento de Zootecnia, CEP: 36570-000, Viçosa, MG.
}

RESUMO - Este trabalho foi realizado para estimar a diversidade genética de 30 acessos de capim-elefante utilizandose marcadores moleculares. Amostras de DNA genômico de cada acesso foram obtidas para realização da amplificação por PCR utilizando a técnica de marcadores RAPD. Foram utilizados 20 primers aleatórios que geraram 88 bandas de DNA de alta intensidade e reprodutíveis (64 bandas polimórficas e 24 monomórficas). Os acessos foram agrupados pelo método UPGMA com base na estimativa das distâncias genéticas. Os grupos de acessos Porto Rico, Santa Rita e IJ-7136 cv. EMPASC 307 e; Mineiro e Mineiro Ipeaco apresentaram distância genética nula entre si, comprovando tratar-se do mesmo material genético com designação diferente. Alguns pares de acessos apresentaram distância genética mínima, como Napier e Mineiro ou Mineiro Ipeaco (0,01); P 241 Piracicaba e Guaçu / IZ2 (0,01); Capim Cana D’África e Vrukwona (0,02); Merker Comum e Merker Comum de Pinda (0,03), indicando tratar-se de genótipos com estreito grau de parentesco. A maior distância genética foi obtida entre os acessos Mercker Comum de Pinda e Napier X 23A (0,34). Os resultados indicam que existe variabilidade genética entre os acessos e que as estimativas de distância genética podem ser utilizadas como critério para seleção de genitores em programas de melhoramento desta gramínea forrageira.

Palavras-chave: marcadores moleculares, Pennisetum purpureum, RAPD, variabilidade genética

\section{Genetic diversity among elephantgrass accessions estimated by molecular markers}

\begin{abstract}
This study aimed to estimate the genetic diversity among Elephantgrass accessions using molecular markers. DNA samples of 30 accessions were obtained to perform PCR amplification using RAPD technique. Twenty random primers were used to obtain 88 high intensity and reproducible DNA bands (64 were polymorphic and 24 were monomorphic). Accessions were grouped by genetic distance estimates using UPGMA clustering. Genetic distances among Porto Rico, Santa Rita, IJ-7136 cv EMPASC 307; Mineiro and Mineiro Ipeaco accessions were null, suggesting that they are genetically the same although labeled with different names. Genetic distances were minimum between the pairs of accessions Napier and Mineiro or Mineiro Ipeaco (0,01); P 241 Piracicaba and Guaçu / IZ2 (0,01); Capim Cana D’África and Vrukwona $(0,02)$; Merker Comum and Merker Comum de Pinda $(0,03)$ and indicate that their genotypes are closely related. The largest genetic distance $(0,34)$ was observed between the Mercker Comum de Pinda and Napier X 23A accessions. Overall, the results indicate genetic variability among accessions and suggest that genetic distance may be used as an auxiliary criterion of selection in breeding programs of elephantgrass genotypes.
\end{abstract}

Key Words: genetic variability, molecular markers, Pennisetum purpureum, RAPD

\section{Introdução}

O capim-elefante (Pennisetum purpureum Schum.) é uma espécie nativa do continente africano comum nos vales férteis com precipitação anual superior a $1.000 \mathrm{~mm}$. Esta forrageira foi introduzida no Brasil no início do século passado e seu cultivo foi disseminado por todo o País por apresentar boa adaptação ao ambiente tropical. O capim- elefante é considerado uma das forrageiras mais importantes, em virtude de suas características de elevado potencial de produção, boa qualidade forrageira e versatilidade de formas de utilização (capineira, ensilagem, feno e pastejo).

A Embrapa Gado de Leite conserva um banco de germoplasmas de capim-elefante com 120 acessos, resultantes da introdução de materiais de diversas coleções brasileiras (Pereira, 1999). Estes acessos já foram caracteri- 
zados quanto aos seus descritores botânico-agronômicos (Shimoya et al., 2002), citogenéticos (Techio, 2002) e isozimáticos (Daher et al., 1997b) e à sua composição química (Carneiro et al., 2002). Estimativas das relações de proximidade genética entre os acessos com base nesses descritores foram realizadas por Shimoya et al. (2002) e Daher et al. (1997a). Embora a caracterização morfológica tenha indicado a existência de duplicatas no banco, os resultados obtidos não foram conclusivos em relação à proximidade genética dos acessos, em razão da natureza variável dos descritores utilizados.

O uso de marcadores de DNA na caracterização de germoplasmas é importante, visto que estes marcadores permitem gerar uma grande quantidade de informações sobre a diversidade genética e os relacionamentos filogenéticos entre os acessos (Ferreira e Grattapaglia, 1996). Além disso, estes marcadores são estáveis, portanto, não sendo sujeitos aos efeitos da interação genótipoambiente que interferem na expressão fenotípica, como acontece com os descritores morfológicos.

A seleção de genitores para os programas de melhoramento e o manejo da variabilidade nos bancos de germoplasma dependem da disponibilidade de informações precisas sobre o grau de divergência genética entre os acessos. Assim, a associação de descritores morfológicos e moleculares pode possibilitar maior conhecimento da variabilidade do germoplasma e seu melhor uso no melhoramento desta forrageira.

Este trabalho foi realizado com o objetivo de estimar a variabilidade genética entre acessos de capim-elefante (Pennisetum purpureum) por meio de marcadores moleculares RAPD.

\section{Material e Métodos}

Foram avaliados 30 acessos do banco de germoplasma de capim-elefante da Embrapa Gado de Leite, localizado em Coronel Pacheco, Minas Gerais. Os acessos avaliados foram: Elefante da Colômbia, Santa Rita, Taiwan 144, Mercker Comum, P 241 Piracicaba, Guaçu / IZ2, Mott, King Grass, Sem pêlo, Porto Rico, Mineiro, Napier, Taiwan A146, Roxo de Botucatu, IJ-7136 CV EMPASC 307, Mineiro IPEACO, Pioneiro, Capim Cana D“África, Napier X 23A, Mercker X 23A, Vrukwona, Cuba 169, Cameroon, IJ-7141 CV EMPASC 306, Kizozi, Mercker comum de Pinda, CNPGL 92_67.3, CNPGL 92_117.3, CNPGL 94_43.1 e CNPGL 94_49.6. Os acessos foram selecionados de acordo com a variação morfológica, a representatividade dos locais de origem e a inclusão de genótipos obtidos em programas de melhora- mento (Shimoya et al., 2002)e constituíram uma amostra da diversidade genética no banco de germoplasma.

Para extração de DNA, amostraram-se $300 \mathrm{mg}$ de folhas jovens expandidas. As amostrasforam mantidas em nitrogênio líquido e posteriormente em freezer $-80^{\circ} \mathrm{C}$. As amostras foram moídas utilizando-se grau com pistilo, na presença de nitrogênio líquido, e transferidas para um tubo de $2 \mathrm{~mL}$. A extração do DNA foi realizada utilizando-se o procedimento do CTAB (Ferreira \& Grattapaglia, 1996). A concentração e qualidade de cada amostra de DNA foi estimada em géis de agarose com padrões de DNA do fago Lambda e também utilizando-se espectrometria com absorbância em 260 e $280 \mathrm{~nm}$.

As reações de amplificação do DNA para obtenção dos marcadores RAPD foram realizadas em um volume total de $20 \mathrm{uL}$ contendo $0,4 \mathrm{mM}$ de primer; $0,2 \mathrm{mM}$ de dNTPs; 1,0 unidade de Taq polymerase; $10 \mathrm{mM}$ de Tris- $\mathrm{HCl}(\mathrm{pH}$ 8,0); $1,5 \mathrm{mM}$ de $\mathrm{MgCl}_{2}$ e $50 \mathrm{mM}$ de $\mathrm{KCl}$. Os seguintes ciclos foram utilizados para amplificação: 40 ciclos, consistindo de $94^{\circ} \mathrm{C}$ por 30 segundos, $37^{\circ} \mathrm{C}$ por 60 segundos e $72^{\circ} \mathrm{C}$ por 30 segundos, seguido de um ciclo de $72^{\circ} \mathrm{C}$, por 7 minutos. As amplificações foram conduzidas em termociclador GeneAmp 9600 (Applied Biosystems). Um total de 20 primers aleatórios foi selecionado da Operon Technologies: OPA02, OPA03, OPA08, OPA09, OPB12, OPC01, OPC02, OPC11, OPD07, OPD18, OPE12, OPE20, OPF09, OPG03, OPG10, OPG17, OPH04, OPH11, OPI02 e OPI09.

Utilizou-se eletroforese vertical em gel de poliacrilamida nativo (8\%), (500 volts, por 1,4 h) com placas de $25 \mathrm{~cm}$. Os géis foram corados com nitrato de prata e os fragmentos foram detectados com o auxílio dos padrões de $200 \mathrm{pb}$ (Figura 1). As imagens dos géis foram digitalizadas em arquivos JPEG e analisadas utilizando-se o software RFLP-Scan (Stratagene Inc.). As bandas de DNA foram exportadas como 1 para presença e 0 para ausência da banda, gerando um arquivo de dados binários.

Os dados binários gerados pela presença e ausência de bandas foram utilizados para se obter uma matriz de distâncias genéticas (NEI \& LI, 1979). Os acessos foram agrupados pelo método UPGMA e as análises realizadas pelo programa Genes (Cruz, 1997). A consistência da topologia do dendrograma construído foi avaliada utilizando-se o método de bootstrap com 10.000 interações.

\section{Resultados e Discussão}

A técnica de RAPD comprovou a existência de polimorfismo entre os acessos de capim elefante, visualizado por meio dos géis de poliacrilamida. Observou-se nítida 
separação dos fragmentos, o que possibilitou a discriminação das bandas de DNA (Figura 1). Os 20 primers de RAPD geraram um total de 88 bandas -64 polimórficas $(72,7 \%)$ e 24 monomórficas (Tabela 1). Para a análise molecular, foram selecionadas apenas as bandas de maior intensidade e que apresentaram repetibilidade. Em média, cada primergerou 4,4 bandas (monomóficas e polimórficas). $\mathrm{O}$ primer $\mathrm{OPH} 04$ foi o mais informativo e produziu nove bandas, enquanto os primers OPC01, OPE12 e OPG17 foram os menos informativos e geraram apenas duas bandas.

Os dados binários foram utilizados para construir uma matriz de distâncias genéticas de Nei (Nei \& Li, 1979) (Tabela 2). A maior distância genética entre dois acessos foi
Tabela 1 - Número de bandas totais (monomórficas e polimórficas) geradas a cada primer de RAPD utilizado para a amplificação do DNA de 30 acessos de capim-elefante (Pennisetum purpureum)

\begin{tabular}{lccc}
\hline Primer & $\begin{array}{c}\text { Número de bandas } \\
\text { de DNA }\end{array}$ & Primer & $\begin{array}{c}\text { Número de bandas } \\
\text { de DNA }\end{array}$ \\
\hline OPH04 & 9 & OPC11 & 4 \\
OPA09 & 6 & OPD07 & 4 \\
OPC02 & 6 & OPF09 & 4 \\
OPE20 & 6 & OPG03 & 4 \\
OPI02 & 6 & OPD18 & 3 \\
OPI09 & 6 & OPG10 & 3 \\
OPA08 & 5 & OPH11 & 3 \\
OPB12 & 5 & OPC01 & 2 \\
OPA02 & 4 & OPE12 & 2 \\
OPA03 & 4 & OPG17 & 2 \\
Total & 88 & & \\
\hline
\end{tabular}

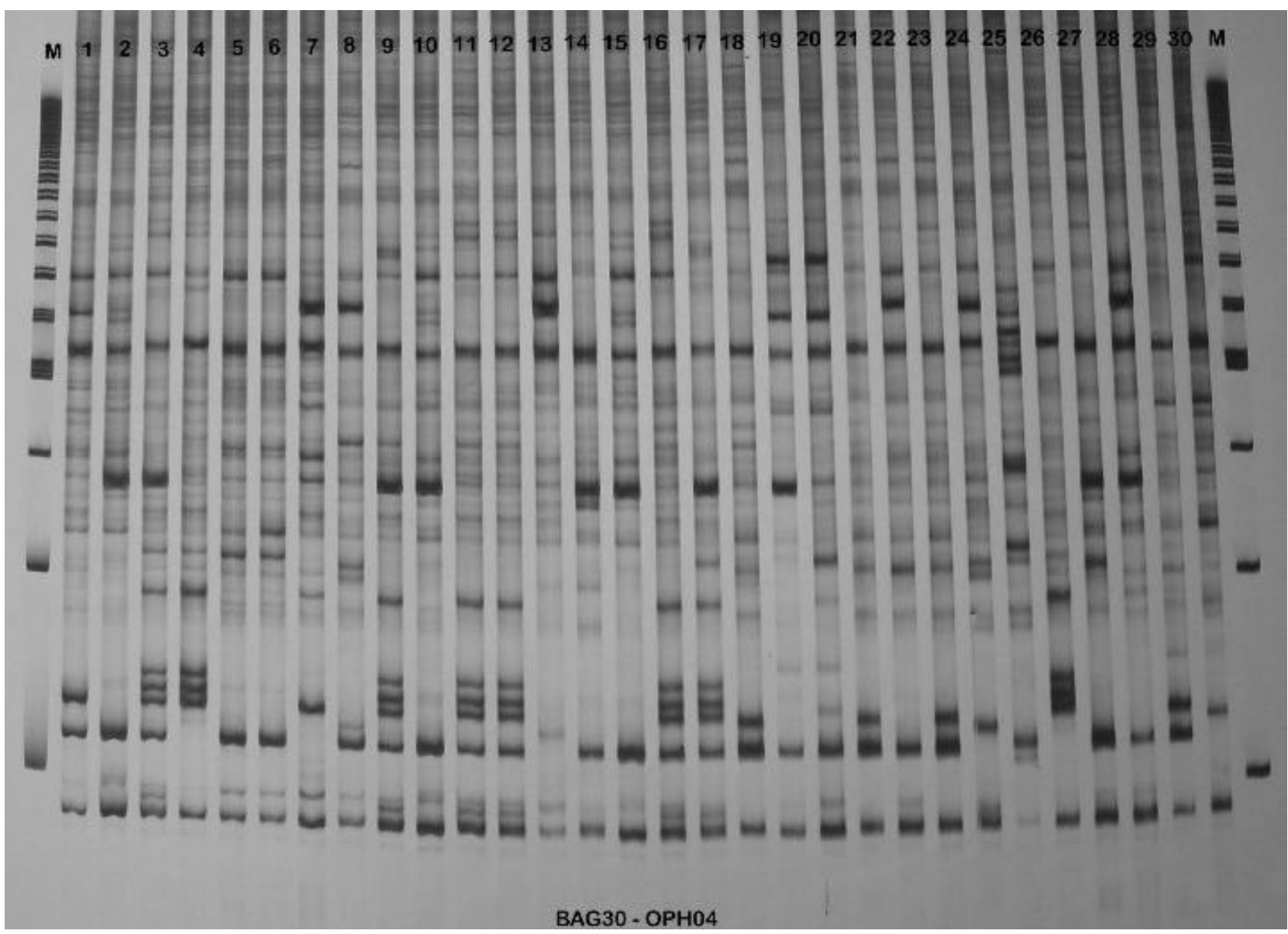

Figura 1 - Padrões de RAPD de 30 acessos de capim-elefante (Pennisetumpurpureum) obtidos com oprimerOPH04. Faixas:M-marcador de 200 pb; 1 - Elefante da Colômbia; 2 - Santa Rita; 3 - Taiwan 144; 4 - Mercker Comum; 5 - P 241 Piracicaba; 6 - Guaçu / IZ2; 7 - Mott; 8 - King Grass; 9 - Sem pêlo; 10 - Porto Rico; 11 - Mineiro; 12 - Napier; 13 - Taiwan A146; 14 - Roxo de Botucatu; 15 - IJ-7136 CV EMPASC 307; 16 - Mineiro IPEACO; 17 - Pioneiro; 18 - Capim Cana D’África; 19 - Napier X 23A; 20 - Mercker X 23A; 21 - Vrukwona; 22 - Cuba 169; 23 - Cameroon; 24 - IJ-7141 CV EMPASC 306; 25 - Kizozi; 26 - Mercker comum de Pinda; 27 - CNPGL 92_67.3; 28 - CNPGL 92_117.3; 29 - CNPGL 94_43.1; 30 - CNPGL 94_49.6 e M - marcador de 200 pb. 
obtida entre Mercker comum de Pinda e Napier X 23A $(0,34)$, o que reflete as diferenças morfológicas e genéticas entre esses acessos: o primeiro, um genótipo de capim-elefante e o segundo, um híbrido triplóide de capim-elefante e milheto.

Os grupos de acessos Porto Rico, Santa Rita e IJ-7136 cv. Empasc 307 e; Mineiro e Mineiro Ipeaco apresentaram distância genética nula entre si, indicando tratar-se do mesmo material genético com denominação diferente (Tabela 2 e Figura 2). Estes resultados estão de acordo com os obtidos por Pereira (1999) sobre a existência de duplicatas no banco de germoplasma da Embrapa Gado de Leite, uma vez que os acessos foram introduzidos de várias coleções e alguns materiais podem ter tido seu nome original modificado. A realização desta análise para o restante dos acessos poderá identificar novas duplicatas no banco de germoplasma.

Alguns pares de acessos apresentaram distância genética mínima entre si - Napier e Mineiro ou Mineiro Ipeaco (0,01); P 241 Piracicaba e Guaçu / IZ2 (0,01); Capim Cana D’África e Vrukwona (0,02); Merker Comum e Merker Comum de Pinda $(0,03)$ - e, provavelmente, são genótipos com estreito grau de parentesco. Resultados similares mostrando estreita proximidade genética entre acessos de capim-elefante, com base em marcadores RAPD, foram obtidos por Daher et al. (2002). O acesso Mineiro, por exemplo, foi selecionado entre progênies do cultivar Napier (Pereira, 1992), portanto, considerando a sua origem, seria esperado alto grau de similaridade genética entre esses acessos. Estas estimativas de distância genética estão de acordo com os resultados de caracterização morfológica realizadas por Shimoya et al.(2002) e Daher et al.(1997b), que encontraram estreita similaridade entre estes pares de acessos.

A amplitude das distâncias genéticas $(0,0$ a 0,34$)$ e a média das distâncias médias dos 30 acessos $(0,21)$ indicam a provável existência de ampla variabilidade genética entre os acessos estudados (Tabela 2). Esses valores são superiores aos encontrados por Faleiro et al. (2005), que obtiveram distâncias genéticas entre 0,07 e 0,24, ao analisarem 12 clones de capim-elefante com base em marcadores RAPD. Lowe et al. (2004), utilizando marcadores RAPD em 49 acessos de capim-elefante, também estimaram a distância genética média em 0,31 a qual consideraram um indicativo de ampla variabilidade genética entre os acessos.

A análise de agrupamento via dendrograma (Figura 2) obtida com base na matriz de distâncias genéticas ilustra a

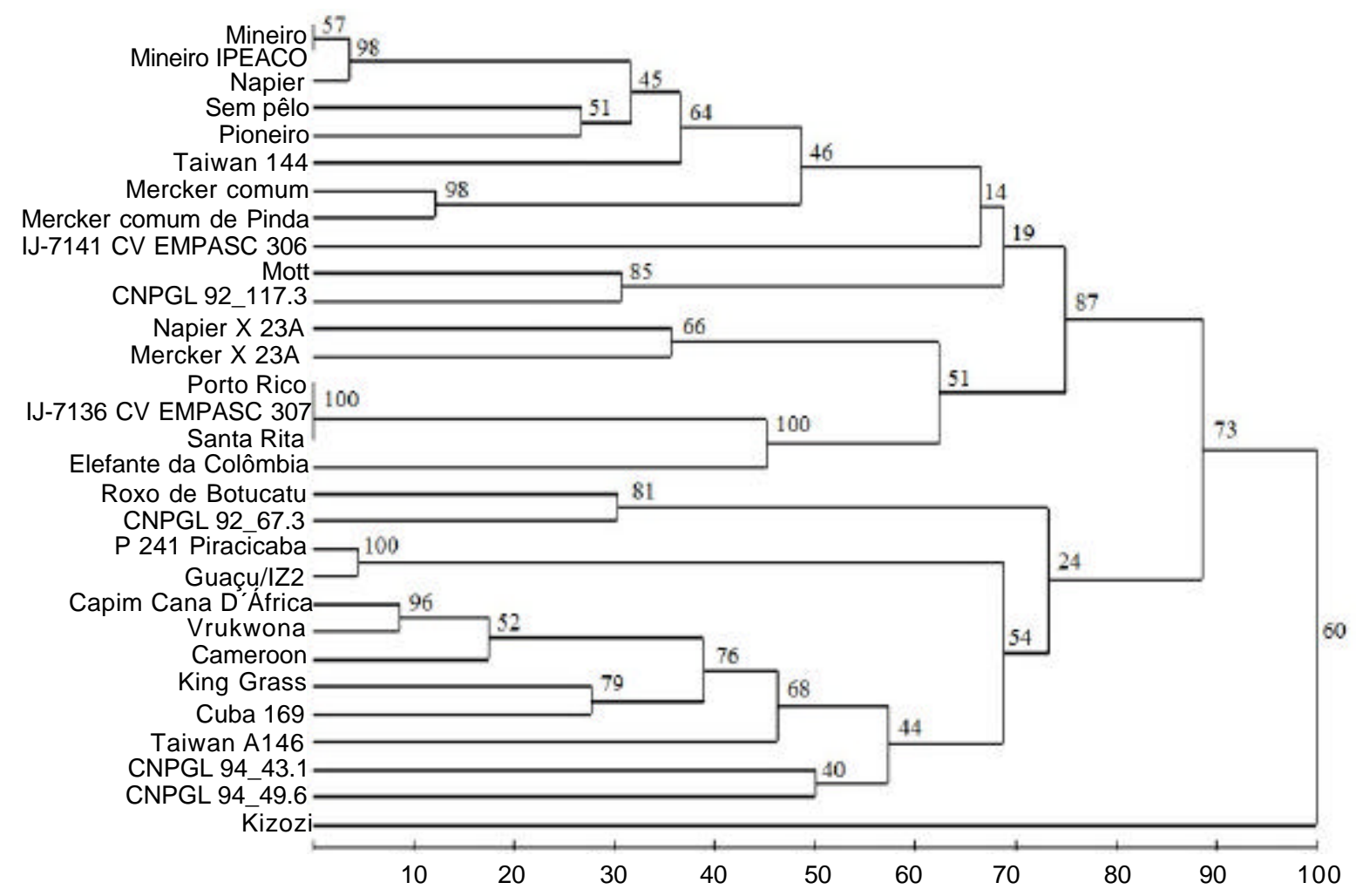

Figura 2 - Agrupamento de 30 acessos de capim-elefante (Pennisetum purpureum), baseado na distância genética de Nei \& Li (1979), obtido utilizando-se o método UPGMA e marcadores RAPD. Os números nas bifurcações representam valores de bootstrap obtidos com 10.000 interações. 
Tabela 2 - Matriz de distâncias genéticas (Nei \& Li, 1979) obtida para 30 acessos de capim-elefante (Pennisetum purpureum) utilizando-se dados moleculares de marcadores RAPD

\begin{tabular}{|c|c|c|c|c|c|c|c|c|c|c|c|c|c|c|c|c|c|c|c|c|c|c|c|c|c|c|c|c|c|c|}
\hline & 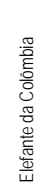 & 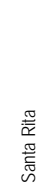 & 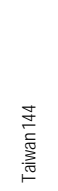 & 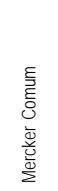 & 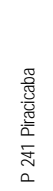 & 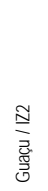 & E & 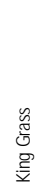 & 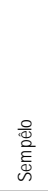 & $\begin{array}{l}\frac{0}{\widetilde{\alpha}} \\
\frac{0}{0} \\
\frac{0}{2}\end{array}$ & 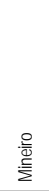 & 高 & 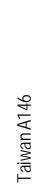 & 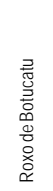 & 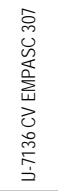 & 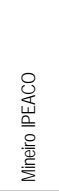 & 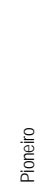 & 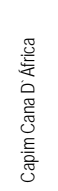 & 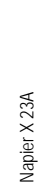 & 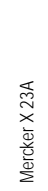 & 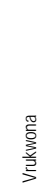 & 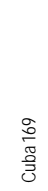 & 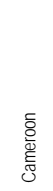 & 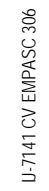 & $\begin{array}{l}\text { N } \\
\text { 岛 }\end{array}$ & 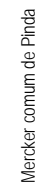 & 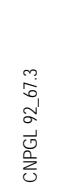 & 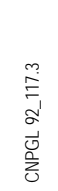 & 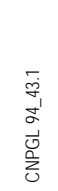 & 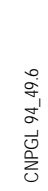 \\
\hline Elefante da Colômbia & & 0,12 & 0,13 & 0,21 & 0,20 & 0,20 & 0,16 & 0,19 & 0,12 & 0,12 & 0,12 & 0,13 & 0,23 & 0,30 & 0,12 & 0,12 & 0,15 & 0,20 & 0,19 & 0,17 & 0,20 & 0,21 & 0,24 & 0,23 & 0,25 & 0,22 & 0,27 & 0,16 & 0,27 & 0,27 \\
\hline Santa Rita & 0,12 & & 0,14 & 0,28 & 0,18 & 0,19 & 0,28 & 0,15 & 0,17 & 0,00 & 0,16 & 0,18 & 0,17 & 0,20 & 0,00 & 0,16 & 0,16 & 0,19 & 0,13 & 0,20 & 0,19 & 0,20 & 0,23 & 0,26 & 0,30 & 0,29 & 0,17 & 0,21 & 0,23 & 0,26 \\
\hline Taiwan 144 & 0,13 & 0,14 & & 0,12 & 0,23 & 0,24 & 0,20 & 0,20 & 0,10 & 0,14 & 0,09 & 0,10 & 0,22 & 0,24 & 0,14 & 0,09 & 0,11 & 0,21 & 0,24 & 0,20 & 0,22 & 0,24 & 0,25 & 0,22 & 0,26 & 0,15 & 0,24 & 0,13 & 0,30 & 0,30 \\
\hline Mercker Comum & 0,21 & 0,28 & 0,12 & & 0,30 & 0,31 & 0,17 & 0,25 & 0,15 & 0,28 & 0,10 & 0,12 & 0,25 & 0,27 & 0,28 & 0,10 & 0,16 & 0,24 & 0,33 & 0,25 & 0,24 & 0,27 & 0,28 & 0,15 & 0,27 & 0,03 & 0,26 & 0,17 & 0,31 & 0,31 \\
\hline P 241 Piracicaba & 0,20 & 0,18 & 0,23 & 0,30 & & 0,01 & 0,30 & 0,14 & 0,22 & 0,18 & 0,22 & 0,21 & 0,19 & 0,24 & 0,18 & 0,22 & 0,24 & 0,18 & 0,19 & 0,21 & 0,16 & 0,19 & 0,20 & 0,26 & 0,32 & 0,31 & 0,18 & 0,24 & 0,20 & 0,25 \\
\hline Guaçu / IZ2 & 0,20 & 0,19 & 0,24 & 0,31 & 0,01 & & 0,28 & 0,15 & 0,23 & 0,19 & 0,23 & 0,22 & 0,17 & 0,25 & 0,19 & 0,23 & 0,24 & 0,16 & 0,20 & 0,22 & 0,17 & 0,20 & 0,20 & 0,27 & 0,33 & 0,30 & 0,19 & 0,25 & 0,21 & 0,24 \\
\hline Mott & 0,16 & 0,28 & 0,20 & 0,17 & 0,30 & 0,28 & & 0,24 & 0,19 & 0,28 & 0,20 & 0,22 & 0,17 & 0,29 & 0,28 & 0,20 & 0,22 & 0,19 & 0,30 & 0,20 & 0,21 & 0,24 & 0,23 & 0,22 & 0,20 & 0,16 & 0,30 & 0,08 & 0,30 & 0,21 \\
\hline King Grass & 0,19 & 0,15 & 0,20 & 0,25 & 0,14 & 0,15 & 0,24 & & 0,26 & 0,15 & 0,21 & 0,20 & 0,10 & 0,20 & 0,15 & 0,21 & 0,23 & 0,10 & 0,22 & 0,25 & 0,07 & 0,08 & 0,11 & 0,23 & 0,27 & 0,26 & 0,12 & 0,21 & 0,14 & 0,15 \\
\hline Sem pê & 12 & 0,17 & 0,10 & 0,15 & 0,22 & 0,23 & 0,19 & 0,26 & & 0,17 & 0,08 & 0,09 & 0,28 & 0,33 & 0,17 & 0,08 & 0,07 & 0,25 & 0,17 & 0,13 & 0,25 & 0,26 & 0,29 & 0,21 & 0,28 & 0,16 & 0,30 & 0,14 & 0,30 & 0,30 \\
\hline Porto Rico & 0,12 & 0,00 & 0,14 & 0,28 & 0,18 & 0,19 & 0,28 & 0,15 & 0,17 & & 0,16 & 0,18 & 0,17 & 0,20 & 0,00 & 0,16 & 0,16 & 0,19 & 0,13 & 0,20 & 0,19 & 0,20 & 0,23 & 0,26 & 0,30 & 0,29 & 0,17 & 0,21 & 0,23 & 0,26 \\
\hline Mineiro & 0,12 & 0,16 & 0,09 & 0,10 & 0,22 & 0,23 & 0,20 & 0,21 & 0,08 & 0,16 & & 0,01 & 0,23 & 0,28 & 0,16 & 0,00 & 0,09 & 0,22 & 0,21 & 0,15 & 0,23 & 0,23 & 0,26 & 0,16 & 0,25 & 0,11 & 0,25 & 0,18 & 0,29 & 0,29 \\
\hline Napier & 0,13 & 0,18 & 0,10 & 0,12 & 0,21 & 0,22 & 0,22 & 0,20 & 0,09 & 0,18 & 0,01 & & 0,22 & 0,29 & 0,18 & 0,01 & 0,08 & 0,23 & 0,22 & 0,16 & 0,22 & 0,22 & 0,25 & 0,16 & 0,26 & 0,13 & 0,24 & 0,19 & 0,28 & 0,28 \\
\hline Taiwan A146 & 0,23 & 0,17 & 0,22 & 0,25 & 0,19 & 0,17 & 0,17 & 0,10 & 0,28 & 0,17 & 0,23 & 0,22 & & 0,18 & 0,17 & 0,23 & 0,25 & 0,12 & 0,25 & 0,25 & 0,12 & 0,15 & 0,14 & 0,20 & 0,25 & 0,23 & 0,17 & 0,21 & 0,22 & 0,15 \\
\hline Roxo de & 0,30 & 0,20 & 0,24 & 0,27 & 0,24 & 0,25 & 0,29 & 0,20 & 0,33 & 0,20 & 0,28 & 0,29 & 0,18 & & 0,20 & 0,28 & 0,30 & 0,20 & 0,27 & 0,32 & 0,20 & 0,20 & 0,21 & 0,30 & 0,27 & 0,30 & 0,08 & 0,24 & 0,27 & 0,27 \\
\hline & & 0,00 & 0,14 & 0,28 & 0,18 & 0,19 & 0,28 & 0,15 & 0,17 & 0,00 & 0,16 & 0,18 & 0,17 & 0,20 & & 0,16 & 0,16 & 0,19 & 0,13 & 0,20 & 0,19 & 20 & 0,23 & 0,26 & 0,30 & 0,29 & 0,17 & 0,21 & 0,23 & 0,26 \\
\hline Mineiro IPEACO & 0,12 & 0,16 & 0,09 & 0,10 & 0,22 & 0,23 & 0,20 & 0,21 & 0,08 & 0,16 & 0,00 & 0,01 & 0,23 & 0,28 & 0,16 & & 0,09 & 0,22 & 0,21 & 0,15 & 0,23 & 0,23 & 0,26 & 0,16 & 0,25 & 0,11 & 0,25 & 0,18 & 0,29 & 0,29 \\
\hline Pioneirc & 0,15 & 0,16 & 0,11 & 0,16 & 0,24 & 0,24 & 0,22 & 0,23 & 0,07 & 0,16 & 0,09 & 0,08 & 0,25 & 0,30 & 0,16 & 0,09 & & 0,24 & 0,20 & 0,17 & 0,22 & 0,20 & 0,26 & 0,20 & 0,25 & 0,17 & 0,24 & 0,18 & 0,26 & 0,27 \\
\hline Capim Cana D’África & 0,20 & 0,19 & 0,21 & 0,24 & 0,18 & 0,16 & 0,19 & 0,10 & 0,25 & 0,19 & 0,22 & 0,23 & 0,12 & 0,20 & 0,19 & 0,22 & 0,24 & & 0,24 & 0,26 & 0,02 & 0,12 & 0,06 & 0,26 & 0,26 & 0,22 & 0,16 & 0,20 & 0,13 & 0,16 \\
\hline Napier X 23A & 0,19 & 0,13 & 0,24 & 0,33 & 0,19 & 0,20 & 0,30 & 0,22 & 0,17 & 0,13 & 0,21 & 0,22 & 0,25 & 0,27 & 0,13 & 0,21 & 0,20 & 0,24 & & 0,10 & 0,24 & 0,22 & 0,28 & 0,29 & 0,33 & 0,34 & 0,24 & 0,23 & 0,19 & 0,22 \\
\hline rccker & 0,17 & 0,20 & 0,20 & 0,25 & 0,21 & 0,22 & 0,20 & 0,25 & 0,13 & 0,20 & 0,15 & 0,16 & 0,25 & 0,32 & 0,20 & 0,15 & 0,17 & 0,26 & 0,10 & & 0,27 & 0,27 & 0,28 & 0,18 & 0,23 & 0,26 & 0,31 & 0,18 & 0,24 & 0,20 \\
\hline Vrukwona & 0,20 & 0,19 & 0,22 & 0,24 & 0,16 & 0,17 & 0,21 & 0,07 & 0,25 & 0,19 & 0,23 & 0,22 & 0,12 & 0,20 & 0,19 & 0,23 & 0,22 & 0,02 & 0,24 & 0,27 & & 0,10 & 0,04 & 0,24 & 0,27 & 0,25 & 0,14 & 0,21 & 0,11 & 0,17 \\
\hline Cuba 169 & 0,21 & 0,20 & 0,24 & 0,27 & 0,19 & 0,20 & 0,24 & 0,08 & 0,26 & 0,20 & 0,23 & 0,22 & 0,15 & 0,20 & 0,20 & 0,23 & 0,20 & 0,12 & 0,22 & 0,27 & 0,10 & & 0,14 & 0,28 & 0,25 & 0,28 & 0,15 & 0,21 & 0,16 & 0,15 \\
\hline Cameroon & 0,24 & 0,23 & 0,25 & 0,28 & 0,20 & 0,20 & 0,23 & 0,11 & 0,29 & 0,23 & 0,26 & 0,25 & 0,14 & 0,21 & 0,23 & 0,26 & 0,26 & 0,06 & 0,28 & 0,28 & 0,04 & 0,14 & & 0,26 & 0,28 & 0,29 & 0,18 & 0,24 & 0,15 & 0,18 \\
\hline IJ-7141 CV EMPASC 306 & 0,23 & 0,26 & 0,22 & 0,15 & 0,26 & 0,27 & 0,22 & 0,23 & 0,21 & 0,26 & 0,16 & 0,16 & 0,20 & 0,30 & 0,26 & 0,16 & 0,20 & 0,26 & 0,29 & 0,18 & 0,24 & 0,28 & 0,26 & & 0,25 & 0,16 & 0,27 & 0,21 & 0,29 & 0,22 \\
\hline Kizozi & 0,25 & 0,30 & 0,26 & 0,27 & 0,32 & 0,33 & 0,20 & 0,27 & 0,28 & 0,30 & 0,25 & 0,26 & 0,25 & 0,27 & 0,30 & 0,25 & 0,25 & 0,26 & 0,33 & 0,23 & 0,27 & 0,25 & 0,28 & 0,25 & & 0,27 & 0,31 & 0,20 & 0,33 & 0,27 \\
\hline Me & & 0,29 & 0,15 & 0,03 & 0,31 & 0,30 & 0, & 0,26 & 0, & 0,29 & 0,11 & 0,13 & 0,23 & 0,30 & 0,29 & 0,11 & 0,17 & 0,22 & 0,34 & 0,26 & 0,25 & 28 & 0,29 & 16 & 0,27 & & 0,27 & 0,18 & 0,32 & 0,30 \\
\hline IPGI 92673 & 0,27 & 0,17 & 0,24 & 0,26 & 0,18 & 0,19 & 0,30 & 0,12 & 0,30 & 0,17 & 0,25 & 0,24 & 0,17 & 0,08 & 0,17 & 0,25 & 0,24 & 0,16 & 0,24 & 0,31 & 0,14 & 0,15 & 0,18 & 0,27 & 0,31 & 0,27 & & 0,23 & 0,21 & 0,24 \\
\hline CNPGL92_117.3 & 0,16 & 0,21 & 0,13 & 0,17 & 0,24 & 0,25 & 0,08 & 0,21 & 0,14 & 0,21 & 0,18 & 0,19 & 0,21 & 0,24 & 0,21 & 0,18 & 0,18 & 0,20 & 0,23 & 0,18 & 0,21 & 0,21 & 0,24 & 0,21 & 0,20 & 0,18 & 0,23 & & 0,30 & 0,25 \\
\hline & 0,27 & 0,23 & 0,30 & 0,31 & 0,20 & 0,21 & 0,30 & 0,14 & 0,30 & 0,23 & 0,29 & 0,28 & 0,22 & 0,27 & 0,23 & 0,29 & 0,26 & 0,13 & 0,19 & 0,24 & 0,11 & 0,16 & 0,15 & 0,29 & 0,33 & 0,32 & 0,21 & 0,30 & & 0,14 \\
\hline & & 0,26 & 0,30 & 0,31 & 0,25 & 0,24 & 0,21 & 0,1 & 0,30 & 0,26 & 0,29 & 0,28 & 0,15 & 0,27 & 0,26 & 0,29 & 0,27 & 0,16 & 0,22 & 0,20 & 0,17 & 0,15 & 0,18 & 0,22 & 0,27 & 0,30 & 0,24 & 0,25 & 0,14 & \\
\hline Distância Média & 0,19 & 0,19 & 0,19 & 0,22 & 0,21 & 0,22 & 0,23 & 0,18 & 0,20 & 0,19 & 0,18 & 0,18 & 0,20 & 0,25 & 0,19 & 0,18 & 0,19 & 0,19 & 0,22 & 0,21 & 0,18 & 0,20 & 0,21 & 0,23 & 0,27 & 0,23 & 0,22 & 0,20 & 0,24 & 0,24 \\
\hline
\end{tabular}

existência de diferentes níveis de proximidade genética entre os acessos analisados. A análise de agrupamento comprovou a formação de vários grupos e, no nível de 0,80 de distância genética relativa, foram definidos três grupos: Grupo 1 com 17 acessos, Grupo 2 com 12 acessos e Grupo 3 com apenas 1 acesso (Figura 2). Pereira (1992) propôs a divisão da variabilidade do germoplasma de capim-elefante em quatro grupos morfológicos: Napier, Merker, Cameroon, Anão e híbridos interespecíficos. Os resultados do agrupamento, com base na análise molecular, corroboram de certa forma a classificação proposta por Pereira (1992), pois o Grupo 1 é constituído por acessos morfologicamente mais próximos dos cultivares Napier e Merker, enquanto o Grupo 2 apresenta maior identificação morfológica com o cultivar Cameroon. Considerando-se a distância genética relativa de 0,80 , os acessos estudados neste trabalho podem ser divididos em dois grandes grupos. Resultado semelhante também foi encontrado por Passos et al. (2005), que utilizaram marcadores RAPD para avaliar a diversidade genética entre dez acessos de capim-elefante.

O Grupo 3, formado pelo acesso Kizozi, destacou-se pela posição isolada no dendrograma, demonstrando ser um material genético muito diverso dos demais acessos avaliados. Esse resultado está de acordo com a avaliação realizada por Shimoya et al. (2002) na qual este genótipo apresentou características morfológicas muito diversas. Também na caracterização citogenética feita por Techio (2002), o acesso Kizozi foi o único a apresentar mixoploidia, o que gera questões sobre sua origem filogenética.

\section{Conclusões}

A técnica de RAPD foi eficiente na detecção de variabilidade genética entre os acessos de capim-elefante analisados. Na amostra do germoplasma de capim-elefante avaliada, existe ampla diversidade genética entre os acessos, o que possibilita a seleção de genitores divergentes para programas de melhoramento. Os acessos identificados pelos marcadores RAPD com distância genética nula entre si constituem duplicatas no banco de germoplasma da Embrapa Gado de Leite que podem ser eliminadas sem risco de perda de variabilidade genética.

\section{Literatura Citada}

CARNEIRO, H.; PEREIRA, A.V.; BOTREL, M.A. et al. Variabilidade no germoplasma de capim-elefante (Pennisetum purpureum Schum) para caracteres associados à qualidade nutricional. In: REUNIÃO ANUAL DA SOCIEDADE BRASILEIRA DE ZOOTECNIA, 39., 2002, Recife. Anais... Recife: Sociedade Brasileira de Zootecnia, 2002. (CD-ROM). 
CRUZ, C.D. Programa genes - aplicativo computacional em genética e estatística. Viçosa, MG: Universidade Federal de Viçosa, 1997, 442p.

DAHER, R.F.; MORAES, C.F.; CRUZ, C.D. et al. Diversidade morfológica e isozimática em capim-elefante (Pennisetum purpureum Schum.). Revista Brasileira de Zootecnia, v.26, p.255-264, 1997b.

DAHER, R,F.; MORAES, C.F.; CRUZ, C.D. et al. Seleção de caracteres morfológicos discriminantes em capim-elefante (Pennisetum purpureum Schum.). Revista Brasileira de Zootecnia, v.26, p.247-253, 1997a.

DAHER, R.F.; PEREIRA, M.G.; PEREIRA, A.V. et al. Genetic divergence among elephantgrass cultivars assessed by RAPD markers in composite samples. Scientia Agricola, v.59, n.4, p.623-627, 2002.

FALEIRO, F.G.; FERNANDES, F.D.; MARTHA JR. G.B. et al. Variabilidade genética de uma coleção de trabalho de capimelefante Pennisetum purpureum com base em marcadores RAPD. In: REUNIÃO ANUAL DA SOCIEDADE BRASILEIRA DE ZOOTECNIA, 42., 2005, Goiânia. Anais... Goiânia: Sociedade Brasileira de Zootecnia, 2005. (CD-ROM).

FERREIRA, M.E.; GRATTAPAGLIA, D. Introdução ao uso de marcadores moleculares em análise genética. 2.ed. Brasília: EMBRAPA-CENARGEN, 1996. p.220. (Documento 20)

LOWE, A.J.; THORPE, W.; TEALE, A. et al. Characterization of germplasm accessions of Napier grass (Pennisetum purpureum and $P$. purpureum $\times P$. glaucum Hybrids) and comparison with farm clones using RAPD. Genetic Resources and Crop Evolution, v.50, n.2, p.121-132, 2003.

NEI, M.; LI, W.H. Mathematical model for studying genetic variation in terms of restriction endonucleases. Proceedings of the National Academy of Sciences U.S.A, v.76, p.52695273, 1979

PASSOS, L.P.; MACHADO, M.A; VIDIGAL, M.C. et al. Molecular characterization of elephantgrass accessions through RAPD markers. Ciência e Agrotecnologia, v.29, n.3, p.568-574, 2005.

PEREIRA, A.V. Germoplasma e diversidade genética do capimelefante. In: PASSOS, L.P.; CARVALHO, L.A.; MARTINS, C.E. et al. (Eds.). Avanços científicos e tecnológicos do capim-elefante. Juiz de Fora: Embrapa Gado de Leite, 1999. p.1-15.

PEREIRA, A.V. Escolha de variedades de capim-elefante. In: SIMPÓSIO SOBRE MANEJO DE PAST AGEM, 10., 1992, Piracicaba. Anais... Piracicaba: Fundação de Estudos Agrários Luiz de Queiroz, 1992. p.45-62.

SHIMOYA, A.; CRUZ, C.D.; FERREIRA, R.P. et al. Divergência genética entre acessos de um banco de germoplasma de capimelefante. Pesquisa Agropecuária Brasileira, v.37, p.971980, 2002.

TECHIO, V.H.; DAVIDE, L.C.; PEREIRA, A.V. et al. Cytotaxonomy of some species and of interspecific hybrids of Pennisetum. Genetics and Molecular Biology, v.25, p.203-209, 2002. 